\title{
HUBUNGAN ANTARA DUKUNGAN SOSIAL ORANG TUA DENGAN KEDISIPLINAN PADA PESERTA DIDIK SMP HASANUDDIN 10 KOTA SEMARANG
}

\author{
Irwan Desyantoro $^{1}$, Sri Widyawati ${ }^{2}$, Mulya Virgonita Iswindari Winta ${ }^{3}$ \\ 1,2,3 Magister Psikologi, Universitas Semarang \\ Jl. Soekarno Hatta, Tlogosari Kulon, Pedurungan, Kota Semarang, Jawa Tengah 59160 \\ irwan.desyantoro@gmail.com
}

\begin{abstract}
Abstrak. Penelitian ini bertujuan untuk menguji secara empirirs hubungan antara dukungan sosial orangtua dengan kedisiplinan pada peserta didik SMP Hasanuddin 10 Kota Semarang. Penelitian ini menggunakan metode kuantitatif jenis deskriptif korelasional. Populasi penelitian adalah peserta didik SMP Hasanuddin 10 Kota Semarang yang berjumlah 592 siswa. Adapun penelitian ini menggunakan rumus Slovin dalam penarikan sampel sehingga responden dalam penelitian berjumlah 107 siswa. Penelitian ini menggunakan pengambilan sampel dengan teknik cluster random sampling. Analisis data berbentuk dilakukan menggunakan teknik koreksi Spearman's Rho. Hasil perhitungan menunjukkan adanya korelasi sebesar 0,333 dengan $\mathrm{p}=<0,01$. Hal ini menunjukkan bahwa ada hubungan yang sangat signifikan antara dukungan sosial orangtua dengan kedisiplinan pada peserta didik, sehinggga hipotesis dalam penelitian ini diterima.
\end{abstract}

Katakunci: Kedisiplinan pada Peserta Didik, Dukungan Sosial Orangtua

\section{Pendahuluan}

Pendidikan merupakan peranan penting untuk bangsa dan negara karena pendidikan dapat meningkatkan dan mengembangkan kualitas sumber daya manusia yang berpotensi. Muhibbin (2014) menyatakan bahwa pendidikan adalah sebuah proses dengan metode-metode tertentu sehingga orang memeroleh pengetahuan, pemahaman, dan cara bertingkah laku yang sesuai dengan kebutuhan. Pendidikan sangat penting dan wajib diperoleh bagi setiap anak di karena dengan pendidikan seorang individu akan memperoleh bekal ilmu dan pengetahuan, keterampilan, pengalaman yang akan bermanfaat bagi dirinya dan orang lain. Soemanto (1998) menyatakan bahwa sala satu tujuan dari pendidikan adalah menolong anak mengembangkan potensinya semaksimal mungkin, dank arena itu bagi pendidikan sangat menguntungkan baik bagi anak maupun bagi masyarakat.

Sekolah merupakan lingkungan dimana individu akan memperoleh bekal ilmu dan pengetahuan yang dapat dimanfaatkan di masa sekarang dan di masa yang akan datang. Peserta didik adalah orang yang terlibat langsung dalam dunia pendidikan sekolah. Djamarah (2008) menyatakan bahwa anak didik adalah subjek utama dalam pendidikan, 
lebih lanjut Riyanto (2002) menyatakan bahwa peserta didik adalah pribadi yang berkemampuan dan hasrat untuk mengembangkan potensi mereka secara optimal. Seorang peserta didik dalam mengikuti belajar di sekolah tidak akan lepas dari berbagai peraturan dan tata tertib yang diberlakukan. Setiap peserta didik dituntut untuk dapat berperilaku sesuai dengan aturan dan tata tertib yang berlaku di sekolahnya. Mematuhi semua peraturan yang berlaku di sekolah merupakan suatu kewajiban bagi setiap peserta didik dengan tujuan para peserta didik dapat belajar mengenai kedisiplinan.

Dalam kehidupan sehari-sehari dikenal adanya disiplin diri, disiplin dalam belajar, dan disiplin dalam bekerja. Seorang dikatakan memiliki disiplin diri yang kuat jika dapat mengendalikan dirinya sendiri. Kerugian akibat dilanggarnya disiplin lazimnya tidak langsung, tetapi berjangka panjang. Keberhasilan belajar peserta didik tidak hanya semata-mata diperoleh dengan mudah, namun membutuhkan proses atau memiliki kebiasan belajar yang baik. Seorang peserta didik yang mempunyai kebiasaan belajar yang baik biasanya mempunyai kebiasaan disiplin dalam belajar yang baik pula. Dalam KBBI (Suharso dan Retnoningsih, 2005) disiplin adalah latihan batin dan watak supaya menaati tata tertib, kepatuhan pada aturan. Kedisiplinan merupakan sikap dalam diri untuk mematuhi dan taat terhadap semua peraturan atau tata tertib yang sudah ada atau berlaku, serta dapat melatih diri untuk bertanggung jawab atas semua tugas-tugas yang sudah menjadi tanggung jawabnya.

Telah menjadi fenomena umum yang terjadi saat ini, bahwa banyak peserta didik yang masih tidak menunjukkan perilaku disiplin di sekolah, sebagai contoh, ada peserta didik yang masih kurang disiplin dalam mentaati peraturan sekolah, mengerjakan tugas saat di kelas, atau ada juga yang mengerjakan tugas tetapi tidak selesai tepat waktu. Adapula peserta didik yang tidak mengerjakan tugas, saat tiba di sekolah dengan menyontek pekerjaan teman, tidak memperhatikan materi yang diberikan, dan belajar jika akan mengahadpi ulangan saja, sehingga semua itu dapat memengaruhi prestasi belajar peserta didik tersebut. Hasil penelitian Indriani dan Muhari (2013) menunjukkan bahwa terdapat sekitar $20 \%$ peserta didik yang mengalami kasus mulai datang terlambat, membolos, memakai atribut seragam tidak lengkap, tidak membawa buku pelajaran, dan kurang memperhatikan pelajaran. Pelanggaran yang dilakukan peserta didik tersebut mengindikasikan peserta didik memiliki perilaku tidak disiplin.

Disiplin di satu sisi merupakan sikap hidup dan perilaku yang mencerminkan tanggung jawab terhadap kehidupan tanpa paksaan dari luar. Sikap dan perilaku ini dianut berdasarkan keyakinan bahwa hal itulah yang benar, dan kesadaran bahwa hal itu 
bermanfaat bagi dirinya sendiri dan masayarakat. Prijodarminta (1994) menyatakan bahwa disiplin adalah suatu kondisi yang tercipta dan terbentuk melalui proses dari serangkaian perilaku yang menunjukkan nilai-nilai ketaatan, kepatuhan, kesetiaan, keteraturan dan atau ketertiban. Kedisiplinan adalah kesadaran dan kesediaan seseorang menaati semua peraturan perusahaan dan norma-norma sosial yang berlaku (Hasibuan, 2013), sedangkan Anoraga (2014) menyatakan bahwa disiplin adalah suatu sikap, perbuatan untuk selalu mentaati tata tertib.

Prijodarminto (1994) menyatakan bahwa terdapat tiga aspek dalam disiplin yaitu, (1) sikap mental, (2) pemahaman yang baik mengenai sistem aturan perilaku, norma, kriteria, dan standar yang sedemikian rupa, sehingga pemahaman tersebut menumbuhkan pengertian yang mendalam atau kesadaran, bahwa ketaatan akan aturan, norma, kriteria dan standar tadi merupakan syarat mutlak untuk mencapai keberhasilan, (3) sikap kelakuan yang wajar menunjukkan kesungguhan hati, untuk mentaati segala hal secara cermat dan tertib. Menurut Sinungan (2014) disiplin mengacu pada pola tingkah laku dengan ciri-ciri yaitu, (1) adanya hasrat yang kuat, (2) adanya perilaku yang dikendalikan, dan (3) kepatuhan dan ketaatan.

Menanamkan sikap disiplin pada peserta didik merupakan tugas semua orang, salah satunya adalah orangtua. Menurut Unaradjan (2003) faktor yang memengaruhi kedisiplinan salah satunya adalah faktor dari luar lingkungan, dimana faktor lingkungan terutama dukungan sosial yang dapat memengaruhi seseorang untuk bersikap disiplin. Orangtua yang selalu mendidik anaknya untuk selalu mematuhi semua peraturan yang ada di lingkungan sekitarnya dan berperilaku tertib itu akan memberikan dampak positif bagi anak. Dampak positif yang diperoleh itu seperti anak dapat bertanggung jawab, tidak suka melanggar peraturan yang ada disekitarnya dan lain sebagainya. Sahputra dan Hutasuhut (2019) dalam hasil penelitiannya tentang kontribusi dukungan orangtua terhadap disiplin siswa memperlihatkan bahwa dukungan orangtua memberikan kontribusi yang signifikan terhadap disiplin siswa sebesar 9,73\% artinya dengan adanya dukungan orangtua dalam mendisiplinkan anak maka unutk mencapai prestasi akan sangat mudah.

Apabila dukungan sosial orangtua pada peserta didik baik maka kedisiplinan peserta didik juga akan menunjukkan kearah yang baik pula, dan apabila dukungan sosial orangtua pada peserta didik rendah atau buruk maka kedisiplinan peserta didik juga akan buruk. Akan tetapi fenomen yang terjadi pada peserta didik SMP Hasanuddin 10 Kota Semarang ini mendapatkan dukungan sosial orangtua yang positif atau baik namun 
berbeda halnya dengan perilaku yang ditampakkan di sekolah, seperti peserta didik yang tidak mematuhi peraturan sekolah dengan melakukan pelanggaran, baik pelanggaran dalam tingkat rendah sampai tinggi.

Menurut Canavan, Dolan dan Pinkerton (Dalam Ayu Sahrul, 2016) dukungan keluarga merupakan tentang mendukung aspek sosial, psikologikal, dan pengembangan pendidikan anak. Sehingga anak merasa nyaman terhadap kahidaran orangtua dan menegaskan dalam benak anak bahwa dirinya diterima dan diakui sebgai individu. Dengan kata lain bahwa dalam segala hal atau aktifitas anak perlu adanya dukungan orangtua, terutama dalam akademik/belajar perlu adanya dukungan baik secara moril dan materil dalam menunjang belajar siswa.

\section{Metode}

Penelitian ini menggunakan metode korelasional, dengan teknik analisis deskirpsi korelasional. Populasi penelitian ini adalah seluruh siswa SMP Hasabuddin 10 Kota Semarang sebanyak 592. Berdasarkan perhitungan menggunakan rumus Slovin dengan presentase kelonggaran $10 \%$ sampel yang menjadi responden dalam penelitian ini sebanyak 107 orang atau sekitar $12 \%$ dari seluruh total peserta didik SMP Hasanuddin 10 Kota Semarang. Teknik dalam pengambilan sampel yang digunakan dalam penelitian menggunakan teknik cluster random sampling dari sejumlah kelas yang sudah dirandom, dihitung jumlah unit sampel sampai memenuhi ukuran sampel minimum yang telah ditetapkan. Instrumen yang digunakan adalah skala model Likert. Analisis data dibantu menggunakan program SPSS v.20.

\section{Hasil}

Deskripsi statistik data hasil penelitian dikelompokan menjadi dua bagian yang terdiri dari data variabel tergantung Kedisiplinan pada Peserta Didik (Y), dan data variabel bebas Dukungan Sosial Orangtua (X). Hasil tabel output data dapat dilihat sebagai berikut.

Tabel 1.

Descriptive Statistics

\begin{tabular}{lccccc}
\hline & $\mathrm{N}$ & Minimum & Maximum & Mean & Std. Deviation \\
\hline KEDISIPLINAN & 107 & 52 & 75 & 64.84 & 5.045 \\
DUKUNGAN SOSIAL & 107 & 65 & 114 & 96.64 & 9.306 \\
ORANGTUA & 107 & & & & \\
Valid N (listwise) & & & & & \\
\hline
\end{tabular}


Dari data diskripsi statistik dapat menunjukkan perhitungan kategori variabel dan distribusi frekuensi yang dituangkan ke dalam tabel sebagai berikut.

Tabel 2.

Kategori X* Kategori Y Crosstabulation Count

\begin{tabular}{|c|c|c|c|c|c|c|c|}
\hline & \multicolumn{5}{|c|}{ Kategori Y } & \multirow{2}{*}{ Total } \\
\hline & & SR & $\mathrm{R}$ & $\mathrm{S}$ & $\mathrm{T}$ & ST & \\
\hline \multirow{5}{*}{ Kategori X } & SR & 1 & 1 & 4 & 2 & 0 & 8 \\
\hline & $\mathrm{R}$ & 1 & 7 & 11 & 3 & 0 & 22 \\
\hline & $\mathrm{S}$ & 3 & 6 & 10 & 12 & 3 & 34 \\
\hline & $\mathrm{T}$ & 0 & 7 & 8 & 16 & 8 & 39 \\
\hline & ST & 0 & 0 & 2 & 2 & 0 & 4 \\
\hline Total & & 5 & 21 & 35 & 35 & 11 & 107 \\
\hline
\end{tabular}

Tabel 3.

Frekuensi Kategori Variabel

\begin{tabular}{|c|c|c|c|c|c|c|c|c|c|}
\hline \multicolumn{6}{|c|}{ Kategori Y } & \multicolumn{4}{|c|}{ Kategori X } \\
\hline & & Frequenc & Percent & $\begin{array}{l}\text { Valid } \\
\text { Percent }\end{array}$ & $\begin{array}{c}\text { Cumulative } \\
\text { Percent }\end{array}$ & Frequency & Percel & $\begin{array}{c}\text { Valid } \\
\text { Percent }\end{array}$ & $\begin{array}{c}\text { Cumulative } \\
\text { Percent }\end{array}$ \\
\hline \multirow[t]{6}{*}{$\overline{\text { Valid }}$} & SR & 5 & 4.7 & 4.7 & 4.7 & 8 & 7.5 & 7.5 & 7.5 \\
\hline & $\mathrm{R}$ & 21 & 19.6 & 19.6 & 24.3 & 22 & 20.6 & 20.6 & 28.0 \\
\hline & S & 35 & 32.7 & 32.7 & 57.0 & 34 & 31.8 & 31.8 & 59.8 \\
\hline & $\mathrm{T}$ & 35 & 32.7 & 32.7 & 89.7 & 39 & 36.4 & 36.4 & 96.3 \\
\hline & ST & 11 & 10.3 & 10.3 & 100.0 & 4 & 3.7 & 3.7 & 100.0 \\
\hline & Total & 107 & 100.0 & 100.0 & & 107 & 100.0 & 100.0 & \\
\hline
\end{tabular}

Berdasarkan tabel di atas, maka dapat diketahui bahwa pada data variabel tergantung $(\mathrm{Y})$ sebagian besar peserta didik memiliki kedisiplinan yang tinggi $(32,7 \%)$, dan hanya sedikit yang memiliki kedisiplinan kategori sangat rendah $(4,7 \%)$, sedangkan pada data variabel bebas $(\mathrm{X})$ sebagian besar peserta didik memiliki dukungan sosial dari orangtua yang tinggi $(36,4 \%)$, dan hanya sedikit yang memiliki dukungan sosial dari orangtua kategori sangat rendah (7.5\%).

\section{Pengujian Asumsi}

Sebelum melakukan uji korelasi terlebih dahulu dilakukan uji normalitas sebaran untuk mengatahui normal tidaknya skor variabel kedisiplinan pada peserta didik dan variabel dukungan sosial orangtua. Selain itu dilakukan uji asumsi untuk mengetahui linieritas hubungan kedisiplinan pada peserta didik dan dukungan sosial orangtua. Hasil data dapat dilihat pada tabel sebagai berikut. 
Tabel 4.

Tests of Normality

\begin{tabular}{lcccccc}
\hline & \multicolumn{3}{c}{ Kolmogorov-Smirnov $^{\mathrm{a}}$} & \multicolumn{3}{c}{ Shapiro-Wilk } \\
\cline { 2 - 7 } & Statistic & $\mathrm{df}$ & Sig. & Statistic & $\mathrm{df}$ & Sig. \\
\hline KEDISIPLINAN & .096 & 107 & .018 & .978 & 107 & .071 \\
DUKUNGAN SOSIAL & .091 & 107 & .028 & .968 & 107 & .012 \\
ORANGTUA & & & & & &
\end{tabular}

a. Lilliefors Significance Correction

Berdasarkan tabel diatas, hasil uji normalitas menunjukkan bahwa variabel kedisiplinan pada peserta didik berdistribusi tidak normal dengan nilai Kolmogorov Smirnov Z 0,096 dimana $\mathrm{p}=0,018$ maka $\mathrm{p}<0,05$. Sedangkan variabel dukungan sosial orangtua bersitribusi tidak normal dengan nilai Kolmogorov - Smirnov Z 0,091 dimana $\mathrm{p}=0,028$ maka $\mathrm{p}<0,05$.

Tabel 5.

ANOVA

\begin{tabular}{|c|c|c|c|c|c|c|c|}
\hline & & & $\begin{array}{l}\text { Sum of } \\
\text { Squares }\end{array}$ & $\mathrm{df}$ & $\begin{array}{l}\text { Mean } \\
\text { Square }\end{array}$ & $\mathrm{F}$ & Sig. \\
\hline \multirow{5}{*}{$\begin{array}{l}\text { KEDISIPLINAN * } \\
\text { DUKUNGAN } \\
\text { SOSIAL } \\
\text { ORANGTUA }\end{array}$} & Between & (Combined) & 765.190 & 33 & 23.188 & .876 & .657 \\
\hline & Groups & Linearity & 222.421 & 1 & 222.421 & 8.399 & .005 \\
\hline & & $\begin{array}{l}\text { Deviation from } \\
\text { Linearity }\end{array}$ & 542.769 & 32 & 16.962 & .641 & .918 \\
\hline & Within $\mathrm{Gl}$ & & 1933.110 & 73 & 26.481 & & \\
\hline & Total & & 2698.299 & 106 & & & \\
\hline
\end{tabular}

Berdasarkan pada tabel di atas tentang pengujian linearitas bahwa $F_{\text {linier }}$ sebesar 8,399 dimana $\mathrm{p}=0.005(\mathrm{p}<0,05)$ menyatakan terdapat hubungan yang bersifat linier antara data variabel dukungan sosial orangtua dan variabel kedisiplinan pada peserta didik.

\section{Pengujian Korelasi}

Setelah dilakukan uji asumsi menunjukkan bahwa data berbentuk nonparametrik, selanjutnya dilakukan uji hipotesis dengan menggunakan teknik korelasi Spearman's Rho untuk menguji apakah ada hubungan antara dukungan sosial orangtua dan kedisiplinan pada peserta didik. Hasil data dapat dilihat pada tabel sebagai berikut. 
Tabel 6.

Correlations

DUKUNGAN
KEDISIPLINAN
ORASIAL
ORANGTUA

\begin{tabular}{clcc}
\hline Spearman's rho KEDISIPLINAN & Correlation & 1.000 & $.333^{* *}$ \\
& Coefficient & & .000 \\
& Sig. (1-tailed) &. & 107 \\
& $\mathrm{~N}$ & 107 & 1.000 \\
DUKUNGAN SOSIAL & Correlation & $.333^{* *}$ &. \\
ORANGTUA & Coefficient & .000 &. \\
& Sig. (1-tailed) & 107 & 107 \\
\hline
\end{tabular}

**. Correlation is significant at the 0.01 level (1-tailed).

Berdasarkan hasil analisis data yang diperoleh diketahui bahwa nilai korelasi 0,333 dimana $p=0,000(p<0,01)$. Hal ini menunjukkan ada hubungan positif yang sangat signifikan antara dukungan sosial orangtua dan kedisiplinan pada peserta didik.

\section{Pembahasan dan Diskusi}

Hasil penelitian ini menunjukkan bahawa ada hubungan positif antara dukungan sosial orangtua dan kedisiplinan pada peserta didik. Semakin tinggi dukungan sosial orangtua, maka semakin tinggi pula kedisiplinan pada peserta didik, begitu pula sebaliknya. Berdasarkan perhitungan koefisien determinasi nilai $\mathrm{r}^{2}=0,11$ dengan koefisien determinasi $11 \%$ dari data tersebut dapat dirumuskan bahwa dukungan sosial orangtua dapat berperan dengan mengkontibusi sebesar 11\% terhadap kedisiplinan peserta didik. Sedangkan 88\% dipengaruhi oleh faktor-faktor yang lain.

Kekuatan hubungan dukungan sosial orangtua dengan kedisiplinan peserta didik dengan koefisien korelasi 0,333. Harga koefisien tersebut menunjukkan bahwa terdapat hubungan yang kecil antara dukungan sosial orangtua dengan kedisiplinan peserta didik ditunjukkan dengan determinasi $\left(\mathrm{r}^{2}\right)$ sebesar 0,11. Hal tersebut bahwa penaikan dan penurunan kedisiplinan peserta didik dipengaruhi oleh tingkat dukungan sosial orangtua sebesar 11\%, sedangkan 88\% dipengaruhi oleh faktor-faktor lain. Hal ini didukung dengan hasil penelitian Wicaksono (2014) bahwa dukungan sosial dan pola asuh mempunyai hubungan yang signifikan dengan kedisiplinan siswa sehingga dapat dijadikan prediktor untuk memprediksi kedisiplinan.

Sebagaimana pendapat Amri (2013) bahwa disiplin menjadi prasyarat bagi pembentukan sikap, perilaku, dan tata tertib kehidupan berdisiplin, yang akan 
mengantarkan siswa sukses dalam belajar. Pendapat Epstein (dalam Santrock, 2003) keterlibatan orangtua dalam sekolah anak yaitu: (1) keluarga mempunyai kewajiban dasar untuk menyediakan keselamatan dan kesehatan bagi anak remaja mereka, (2) sekolah mempunyai dasar untuk berkomunikasi dengan keluarga mengenai program sekolah dan perkembangan anak mereka, (3) keterlibatan orangtua di sekolah harus ditingkatkan, (4) keterlibatan orangtua dalam aktivitas belajar di rumah harus ditingkatkan, (5) orantua harus lebih sering terlibat dalam pengambilan keputusan di sekolah, (6) kolaborasi dan kerjasama dengan organisasi di masyarakat ditingkatkan.

Hasil penelitian ini sejalan dengan hasil penelitian yang dilakukan oleh Hidayat (2013) tentang peningkatan kerjasama antara guru dengan orangtua untuk perserta didik yang dibangun melalui komunikasi formal dan non-formal dapat meningkatkan berperilaku disiplin peserta didik dalam mengikuti proses belajar mengajar di sekolah. Hal ini dapat dikatakan bahwa semakin baik tingkat kerjasama orang tua dengan guru di sekolah maka akan berdampak pada semakin meningkatnya disiplin peserta didik dalam mengikuti proses belajar mengajar di sekolah, dan sebaliknya jika kerjasama orang tua dengan guru kurang erat maka akan berdampak pada semakin rendahnya disiplin peserta didik.

Hal ini mendukung pendapat Unaradjan (2003), yang berpendapat bahwa faktor timbulnya sikap disiplin salah satunya ada pada faktor eksternal yaitu keadaan keluarga yang merupakan tempat pertama dan utama pembinaan pribadi. Keluarga dapat menjadi faktor pendukung atau penghambat usaha pembinaan. Hal ini tergantung dari keadaan keluarga tersebut. Orangtua merupakan orang yang pertama dan utama yang bertanggung jawab terhadap kelangsungan hidup dan pendidikan anaknya. Sebagai orangtua harus dapat membantu dan mendukung terhadap segala usaha yang dilakukan oleh anaknya serta dapat memberikan pendidikan informal guna membantu pertumbuhan dan perkembangan anak tersebut serta untuk mengikuti atau melanjutkan pendidikan formal di sekolah.

Ketika peserta didik tidak dapat mengontrol perilakunya, orangtua akan memberikan dukungan instrumental yang merupakan jenis dari dukungan sosial dapat berupa pertolongan langsung seperti pinjaman uang, pemberian barang, makanan serta pelayanan. Orangtua yang mampu menunjukkan dukungan instrumental terhadap anak, seperti halnya reinforcement berupa uang apabila dapat berperilaku baik dan menaati tata tertib di sekolahan dapat menunjang kedisiplinan peserta didik. 
Philanthropy Journal of Psychology

Vol 4 Nomor 1 (2020), 34-44

ISSN 2580-6076 (Print), ISSN 2580-8532 (Online)

Peserta didik yang mendapatkan dukungan sosial dari orangtua akan mendapatkan suatu bantuan baik secara langsung, berupa penjelasan mengenai berperilaku yang baik di dalam sekolahan atau secara tidak langsung, sehingga setiap perbuatan yang dilakukan peserta didik dapat dipertanggungjwabkan dan peserta didik dapat menjadi pribadi yang disiplin.

Disiplin yang baik itu mencerminkan besarnya rasa tanggung jawab seseorang terhadap tugas-tugas yang diberikan kepadanya. Tanggung jawab diri peserta didik harus dapat diterapkan dalam berbagai hal termasuk diantaranya tanggung jawab dalam mematuhi semua peraturan sekolah. Dengan disiplin, rasa malas, rasa enggan dan rasa menetang dapat teratasi sehingga peserta didik akan belajar sesuai harapan-harapan yang terbentuk di lingkungan, baik itu lingkungan keluarga, lingkungan sekolah, maupun lingkungan masyarakat.

Kedisiplinan mutlak adanya, karena dengan kedisiplinan individu akan terbiasa dengan beban yang diemban sebagai pelajar yaitu menjadi pelajar yang cerdas, berakhlak dan bersaing dengan bangsa-bangsa lain serta memberikan kebahagiaan bagi kedua orangtuanya. Kedisiplinan merupakan modal utama untuk meraih keberhasilan, dengan disiplin seseorang akan terbiasa dengan hal-hal yang membuat dirinya bisa berkembang, mengerjakan sesuatu tepat waktunya dan mengembangkan potensi yang ada pada dirinya. Hal ini tentunya sejalan dengan peran dari dukungan sosial dari orangtua mengenai penanaman sikap disiplin, apabila dukungan sosial dari orangtua tinggi terhadap perkembangan dan pendidikannya, maka peserta didik tersebut akan senang dan akan menjadi pribadi yang bertanggung jawab.

\section{Simpulan}

Berdasarkan analisis data dan hasil penelitian yang dilakukan dapat diambil kesimpulan bahwa ada hubungan positif yang signifikan antara dukungan sosial orangtua dengan kedisiplinan pada peserta didik SMP Hasanuddn 10 Kota Semarang. Hal ini berarti semakin besar dukungan sosial dari orangtua yang diberikan subjek maka semakin tinggi kedisiplinan pada peserta didik, demikian juga sebaliknya semakin kecil dukungan sosial dari orangtua yang diberikan subjek maka semakin rendah kedisiplinan pada peserata didik dengan demikian hipotesis dalam penelitian diterima. 


\section{Daftar Pustaka}

Amri, Sofan. (2013). Pengembangan dan Model Pembelajaran dalam Kurikulum 2013. Jakarta: Prestasi Pustaka.

Anoraga, P. (2014). Psikologi Kerja. Jakarta: Rineka Cipta.

Azwar, Saifuddin. (2016). Dasar-dasar Psikometrika. Yogyakarta: Pustaka Pelajar.

Djamarah, S.B. (2008). Psikologi Belajar. Jakarta: Rineka Cipta.

Hasan, M. Iqbal. (2005). Pokok-pokok Materi Statistik 2 (Statistik Inferensif). Jakarta: Bumi Aksara.

Hasibuan, M.S.P. (2013). Manajemen Sumber Daya Manusia. Jakarta: Bumi $\quad$ Aksara.

Hidayat, H. Syarif. (2013). Pengaruh Kerjasama Orangtua dan Guru terhadap Disiplin Peserta Didik di Sekolah Menengah Pertama (SMP) Negeri Kecamatan Jagakarsa Jakarta Selatan. Jurnal Ilmiah WIDYA. Vol. 01, No. 02, hlm. 92 - 99.

Indriani, S., dan Muhari, H. (2013). The Implementation of Reality Group Counseling to Improve Discipline Behaviour Student Class VIII - G In State Junior High School 28 Surabaya. Journal Mahasiswa Olahraga dan Kesehatan. Vol. 01, No. 02, hlm. 37 - 43.

Kumalasari, F., dan Ahyani, Latifah N. (2012). Hubungan antara Dukungan Sosial dengan Penyesuaian Diri Remaja di Panti Asuhan. Jurnal Psikologi Pitutur. Vol. 01, No. 01, hlm $21-31$.

Nawawi, H. Hadari. (2005). Metode Penelitian Bidang Sosial. Yogyakarta: Gadjah Mada University Press.

Prijodarminto, S. (1994). Disiplin Kiat Menuju Sukses. Jakarta: Abadi.

Riyanto, T. (2002). Pembelajaran sebagai Proses Bimbingan Pribadi. Jakarta: Grasindo.

Sahputra, Dika dan Hutasuhuti, Dina H. (2019). "Kontribusi Dukungan Orangtua terhadap Disiplin Belajar Siswa". Enlighten: Jurnal Bimbingan dan Konseling Islam. Vol. 02, No. 01, hlm 35-39

Santrock, J.W. (2009). Psikologi Pendidikan: Educational Psychology. Terjemahan oleh Achamd Chusairi dan Duda Damanik. Jakarta: Kencana.

Sinungan, M. (2014). Produktivitas: Apa dan Bagaimana. Jakarta: Bumi Aksara.

Soemanto, W. (1998). Psikologi Pendidikan. Jakarta: Rineka Cipta.

Suharso dan Retnoningsih, A. (2005). Kamus Besar Bahasa Indonesia. Semarang: Widya Karya.

Syahrul, Ayu. (2016). Kontribusi Keharmonisan Keluarga dan Hubunan Teman Sebaya terhadap Motivasi Belajar Siswa serta Implikasinya dalam Bimbingan dan Konseling. Tesis. Tidak dterbitkan Universitas Negeri Padang: Padang. 
Philanthropy Journal of Psychology

Vol 4 Nomor 1 (2020), 34-44

ISSN 2580-6076 (Print), ISSN 2580-8532 (Online)

Syah, M. (2014). Psikologi Pendidikan. Bandung: Remaja Rosdakarya.

Unaradjan, D. (2003). Manajemen Disiplin. Jakarta: Grasindo.

Wicaksono, D. Ary. (2014). Kedisiplinan Siswa Ditinjau dari Dukungan Sosial dan Pola Asuh Otoriter Orangtua pada Siswa yang Berlatar Belakang Berbeda (TNI dan NonTNI). Jurnal Widya Warta. No. 01, ISSN 0854-1981. 